\title{
Ethical Principles Under the Challenge of Enhancing Medecine
}

\author{
Ismaila Mboutngam \\ Departement of Philosophy, Faculty of Arts, Letters and Social Sciences, The Univerty of Yaounde 1, Yaoundé, Cameroon
}

Email address:

i.mboutngam@yahoo.com

\section{To cite this article:}

Ismaila Mboutngam. Ethical Principles Under the Challenge of Enhancing Medecine. International Journal of Biomedical Engineering and Clinical Science. Vol. 7, No. 1, 2021, pp. 7-13. doi: 10.11648/j.ijbecs.20210701.12

Received: October 3, 2020; Accepted: November 5, 2020; Published: March 12, 2021

\begin{abstract}
Our purpose in this article is to make a prospectivist evaluation of the enhancing medicine regarding the human nature. From this, we are interested by the future of humanity within the project of artificializing human life. In order to achieve our epistemological aim, we have distributed this work into three main parts. The first part is an analysis of medical ethical principles that are presented as the safety belt of human nature. The human being within Hippocratic tradition of medicine has always been treated with certain consideration since he is an absolute value. In all circumstances, physicians were bound to preserve live and protect human dignity. Then, the medical paradigm prevailing was the therapeutic one. In the second part, the concern is to scrutinize the biotechnological revolution mainly the process of genetic engineering. This revolution brought alongside medical practices another version of treating human being. It is the version of higher experimentation and scientific curiosity. Therefore, the practitioners of genetic engineering proceed by a profound intervention in human genome in order, not mainly to cure disease, but to discover what makes life and others human functions be possible. When these are discovered, they can program, design and enhance the future human being. This practice cannot go on without raising ethical questions such as the risk of alteration of human nature. It can also bring in the society the social injustice, giving the fact that those practices are more expensive to be at the level of all the social classes. The most eminent consequence of this social injustice is what we name bioimperialism where the natural human beings will become the slaves of artificial and enhanced human beings. Finally, we will bring a new perspective to contain the risks of enhancing medicine. It is necessary that man must recognize the limits of his power and the effects that the overuse of that power can generate as disasters. However, it is also relevant to notice that, enhancing medicine has already gained public opinion. Accordingly, theorical discourses of bioethicists and philosophical pessimism are not more able to bind the biomedical progress. What is important for bioethicists and humanity as whole, is a habitude of resilience consisting not of rejecting categorically the biomedical practices but to appreciate them according to the good there are able to achieve.
\end{abstract}

Keywords: Ethics, Enhancing Medicine, Human Nature, Transethics, Resilience

\section{Introduction}

The more human knowledge grows, the less his value is saved. During the last two decades, humanity has discovered several innovations brought about by advances in biotechnology. In the medical domain, we have seen a great revolution by which the old paradigms were put aside. In the classical paradigm of medecine, the purpose of any practice was to restore injuries and this was called therapeutic medecine.

The physicians hence, were bound to protect life, to save from death and to respect patients' autonomy. Within this period, the sanctity of human dignity and the sacrality of human nature were sacrosaint principles. This was the content of the Hippocraticum corpus in which the patient or human being in general, was considered as an absolute value and should be prevented from suffering and any other experimental curiosity except for the purposed of caring. The advent of new biomedical technology, in the twentieth century, operated an epistemological rupture between two medical paradigms: the therapeutic medecine and the enhancing medecine.

With the enhancing medicine, the purpose of physians is not only to restore health but mostly to increase, to improve or even to enhance physical or psychological capacities of human beings. It occured with genetic enhancement which refers "to 
genetic modification which improves the function of some system [1]." Genetic modification can consist of selecting genes of futur child, increasing capacity of certain human organs like sigth, breathing or hearing. The aim of these practices is to enable human beings to go beyong the normal capacity laid by nature. However, the modificaton in itself is not wrong when it figths against certains disabilities and prevents some congenital diseases. Giving the onerous cost of enhancing medecine, the immixtion of neolibralism, it is relevant to raise ethical questions concerning the destiny of human nature and the future of our society made up by manufactured human beings. Our world is going to be shaked during the twenty first century by the artificial human being or the Transhuman. As such, there are obvious ethical questions that we can not overlap. Can an enhanced human keep the fundamental qualities of a natural human being? How relevant should our conception of human nature be rethought?

\section{Ethical Principles as the Safety Belt of Human Dignity}

The human being has always been the priority of all philosophical preoccupations. As far as medical practices are concerned, his value was protected by some funcdamental ethical principles. Those principles stood as the savety belt which prevented physicians from all the attempt to alter human nature. Among the funcdamental ethical principles, we have the four major ones: beneficience, non-maleficience, autonomy and justice.

\subsection{The Sanctity of Human Life in the Hippocraticum Corpus}

In the classical paradigm of medicine, the sanctity of human life imposed to physician the sense of respect, resposability and a comitment in the exercise of his profession. At the time that a physician graduated and called to integrate in the medical corpus, Hippocratus substancially recommended him to swear: "I will use treatment to help the sicks according to my ability and jugment, but I will never use it to injure or wrong them [2]." This oath lead to the medical ethical principles of beneficience. According to this principle, the effort of medical doctor consists of using the normal means to cure his patient. In this case, physicians must show humility, do his work carefully to avoid damage or hardship on patients.

Accordingly, the beneficience principle logically infers to non-maleficience ethical principle. In fact, by doing the good physician avoids harm. Further, the Hippocratic Oath bound medical doctor to "be useful or at least not to harm [3]." That is what means in Latin words primum non nocere. To this extend, Hippocrates is custumary considered as the author of deontological rules that were set down in the Fifth century. From these deontological rules, we can bring out the norms of proper conduct of the practitioner towards his patients. At that time, the patient was not considered as the client, as it is the case within the neoliberal context. He was a subject endowed with sacred values to be protected. In this medical framework, the physician had no rigth to make any experimentation on patients.

It is necessary to precise that the sanctity of human life does not mean that the human being is untouchable or must not be submitted to any process of improvement. The worry is about any process of enhancement which attempts to alter or change human nature; that is what we see as ethically wrong. Biomedical practices like active euthanesia, brain death argument, gene selection are usually involved not for the interest of patient or human nature but for utilitarian and mercantile motivations. For instance:

Traditional ethics...never asks whether the patient's life worthwhile, for the notion of a worthless life is as alien to the Hippocratic tradition as it is to English criminal law, both of which suscribe to the principle of the sanctity of human life which holds that, beacuse all lives are intrinsically valuable, it is always wrong intentionally to kill an innocent human being [4].

We notice that, the respect of the sanctity of human life was being challenged by enhancing medecine in the middle of Twentieth century, precisely during the Second World War where some drugs were injected into soldiers to enhance their strength in the battle field. In the process of increasing the capacity, the human being can no longer keep his physical and moral integrity. In this sense, he stands as an object of scientific tentative.

\subsection{Human Being as Imago Dei: A Sacred Value}

According to the Judeo Christian tradition, the human being reflects the image of God. As such, his autonomy and his will must be respected and promoted. This implies that no human being, no matter the reason, has no right to intervent in changing the life of other human being. Everything that should happen to a human being, must come from God or nature. This sacrality of human life led the Greek philosopher, Protagoras to define man as "the measure of all things". It seems that nothing worths human being and human being worths everything.

This anthropocentric conception of the human being was deeply shakened by the Copernican Revolution whereby, the human being was shifted from the center of universe to the periphery. From an absolute value, he becomes a relative one on which all scientific manipulations and ethical jugment are authorised.

Peter Singer, a postmodern bioethicist, looked at this as the greatest "revolution without opposition." The author went beyond that revolution and poceeds in a refoundation of biblical commandments. His obstination carried out the substitution of the old commandments by the new ones. The one that retains our attention is the first old commandment which claimed that "treat all human life as of equal worth." Singer thinks that this old commandment must be changed by a new one because the human being is no more an absolute value. What he called the first new commandment states that "recognize that the worth of human life varie."

This heretic revolution conducted by Singer has lead to 
moral relativism, scientific curiosity and genetic manipulation going on in the current biotechnologies. The human being henceforth, is an object which can be treated without scrupulousness and careness. He can also be used for all the purpose and the most immoral attempt is to increase benefit. Under the biotechnological process, human nature is threatened to deteriorate or to disappear. Is the human being still an absolute value as Kant claimed? Not at all. The expanded neoliberalism which controls biotechnological activities set down the capitalistic vision of human being. $\mathrm{He}$ is taken as a means to mercantilistic end. Whereas, in Kantian ethics, human dignity is worthful as set in this maxime "act that you treat humanity, whether in your own person or in the person of any other, always at the same time as an end, never merely as a means [5]." Scientists looked at this categorical principle as a bareer to their investigation. That is why ethical revolution and moral relativism favoured scientists by giving them more freedom in their activities. This ethical revolution is qualified by Peter Singer as the "Collapse of our traditional ethics". Henceforth, man aspires to fullfil his desires, to express his power and to master not only the nature, but his own life through medical intervention in human genome. The mutations which result from medical intervention in the secret of human life brought more trouble in ethics and threaten human nature.

The ethical worries are more afflicting today because biotechnologies evolve at a very higher speed and the consequences in the future are going to be untenable. This work, once more, is an alert to humanity of what might happen to mankind as bad effects of man overpower in the universe and on his own life.

\section{Enhancing Medecine as the Threat to Human Nature}

In the philosophical view, it will be dishonest to deny the advantages of biotechnologies. The innovations performed in the medical domain has supplied to humanity a certain suitable well-being. Through biomedical revolution, human beings can live well and be proud of being human. Congenital malformation can be fought by preventive medecine. Sterility can also be given a solution through assisted medical reproduction and give social stability to some couples. The most fundamental revolution to be appreciated concerns a profound cerebral disable adult who has recovered his mental ability. In fact:

It is a quadriplegia adult of 20 years old having a damage in the spinal cord who has recently recovered the cortical control of functional movement due to an electronic puce of 1.5 millimeter inserted in into his cerebral cortex and 96 electrodes joined to the muscles of his arm [6].

We have to notice that, up till now, both physical and cerebral disabilities have been seen as natural fatalities. Paralysed infant, deaf and blind human beings have been suffering from natural unjustice and social stigmatisation. In this side, biomedical technology comes as a solution to natural injuries by fortifying the human being with what nature deprived him from. This is the reason why biotechnology fascinated everybody and is considered today as the religion of humanity. Trusting biotechnology must not lead us to obliterate and overlap the potential dangers that can or will happen to humanity. We recall that the dangers occur when biotechnology goes beyond therapy or restoration and pretends to manufacture human beings.

\subsection{Enhancing Medecine: An Alteration of Human Nature}

For the human being to have dignity, there is a need for his organism to keep an integrity. When his organism become a field of scientific experimentation, necessarily, his integrity will be disturbed and his dignity lost. Enhancing medicine is on the line of profound intervention over what is supposed to insure human integrity: the human genome. The common error of biotechnologists is their conception that human genome can only be explained from a physical view. Despite the mastering of human evolutionnary process by genetic engineering, there are hidden factors which interfere in the genetic constitution of human beings such as environment, history, cultures...; those hidden factors come into the epigenetic process.

When the practitioners of enhancing medecine proceed by a modification of human genome, by a selection of the genetic caracteristics of a future child, it is obvious that the nature of that child is already altered. This alteration has ethical consequences as privation of autonomy and self determination of the future child, the desintegration of future generation and the obliteration of human species. To this extend, the red line is crossed by bioprogressists for whom biotechnology has no limit and must master and refound human nature. On the other side, bioconservators and bioethicists such as Hans Jonas, Leon Kass, Habermas call for vigilance about the biotechnological activities. For Hans Jonas, genetic enhancement opens up:

A Pandora's Box of melioristic, unpredicable, inventive, or simply perverse-curious adventures, adandoning the conservative spirit of genetic repair for the path of creative arrogance. We are not authorized to do this, and we are not equiped for it - not with the wisdo, not with the knowledge of value, not with the self-discipline. And no longer will a tradition of reverence protect us, the demystifies of the world, from the enchantment of thoughtless crime. Therefore, let the box remain unopened [7].

If the Pandora's Box is opened, the future will be dark and our knowledge will not be able to contain the risks. It is the funcdamental duty of bioethicists to call for concern and take their responsabilty in order to inform humanity of what might happen if nothing is done. It is important to alert and denounce the silent project of genetic engeneering to awake direct actors on the untenable future. Georges Annas, an American bioconservator is more apocalypticaly in describing genetic manipulation that he qualifies as "genetic genocide, with species-altering genetic engeneering a potential weapon of massive destruction that makes the 
unaccountable genetic engeneer a potential bioterrorist [8]."

The question of human nature must be preeminent in the bioethics debates since enhancing medecine gains public opinion. When biotechnologists let people only know that they have the right and possibility to choose what they like for them and for others, they don't care about the outcomes and consequences of their action. Fortunalty, The President's Council Report on Bioethics, entitled Beyond Therapy [9] was strongly critical of human enhancement. The Committee looked at the use of biotechnologies to alter and enhance human being as threats to human nature and dignity. From this perspective, Michael Sandel scrutinises genetic enhancement and for him, the problem of that practice,

Lies in the hubris of the designing parents, in their drive to master the mystery of birth.... It would disfigure the relation between parent and child, and deprive the parent of the humility and enlarged human sympathies that an openness to the unbidden can cultivate.... The promise of mastery is flawed. It threatens to banish our appreciation of life as a gift, and to leave us with nothing to affirm or behold outside our own will [10].

The consequences of new biotechnologies as we said, might be apocalyptic and humanity might be unable to support them. Sometimes, the extreme desire of man to master nature and express his will make him blind of the effects that the failure of that mastery can generate. Human nature is already altered and consequences are soon to be obseved. Another consequence of enhancing medecine that will overthrow the social life is social injustice that we call bioimperialism.

\subsection{The Quest for Perfection and the Advent of Social Injustice: Towards a Bio-imperialism}

As a funcdamental ethical principle, justice in medical pratice recommends physicians the obligation to treat patients with equal ease, to make medical ressources availlable for all the patients regardless their social and financial status. However, new biotechnologies are far from giving opportunity of equal access to all the social classes. The practice of enhancing medecine has to do with multinationals and people of very high financial means. For instance, the process to select human genome for a future child is of an exorbitant cust and only rich people can have access to that practice.

Rich parents will select genes to make intellegent children and poor one will only rely on the genetic lotery of the nature that may produce intelligent or stupid children. Also, people of high financial means will increase their sight in order to see more or those who will use chemical substances to enhance their energy in sportive and economic activities. The convergencing technology NBIC (nanotechnology, biotechnology, information technology and cognitive science) provides the human being with the possibility to upgrade his mind and remain always young. This technique is called mind uploading by which the memory is connected to internet. There is in this line some drugs named "neuroenhancers used to enhance intellectual capacities like
Adderall, monadafinil, donepezil [11]." The problem with these pratices is that, they are too expensive and only privileged people can use them.

When enhancing medecine will fullfil the project of genetic selection, an unequal society will advent. There will be in the same society ultra intelligent human beings on one side and the unintelligent ones on the other side. Unavoidably, our society will face a genetic apartheid where natural human beings will be the slaves of enhanced ones. This is what we call the bio-imperialism. This will not oppose two continents, as it is the case in political imperialism, but inside the same country, same family, there will be a gap between citizens. Natural human beings will merely be considered as what the transhumanist Kevin Warwick refers to as "the chimpanzee of the future [12]." Qualifying natural the human beings as chimpenzees is what according to Warwick will be more catastrophic for our future. Bio-imperialism will lead to social desintegration where people of different genetic status will see themselves as enemies and there will be no more solidarity. For Julian Savulescu:

These would be mere consumer decisions - but that also means that they would benefit the rich far more than poor. They would take the gap in power, wealth, and educatio that currently divides both our society and the world at large, and write that division into our very biology. Enhancement will create a two - class society of the enhanced and the unenhanced, where the inferior unenhanced are discriminated against and disadvantaged all through life. This is represented in the film Gattaca [13].

The problem of social justice raised by enhancing medecine is considered by Leo Kass as a central issue. "The central issue is an unfair advantage and distributive justice: the question of the fairness of some people being able to access advantageous technologies while others are not [14]." Also, the fact that parents have control on genetic constitution of their future children might create an alteration between generations. Leon Kass thinks that "even partial control over genotype would add to existing social instruments of parental control and its risks of despotic rule. This is indeed one of the central arguments against human reproductive cloning: the charge of genetic despotism of one generation over the next."

Above all, enhancing medicine, from the néoliberal conception, is an attempt to purify our society from natural human beings considered as defectuous and imperfect. It is a political eugenism in which importance is given to a manufactured human being than to the natural one. The apocalyptic society is near, our society is going to change and our relationship to others (enhanced) will profoundly be alterated. In man's quest for immortality, enhancing medicine proposed solution to stop aging and enable the human being to live longer and healthy. The transhumanist biologist Aubrey de Grey announces that "the first man who will live for 1000 years is already born [15]." If this prophecy is to be realized, how are we going to be in a society where some people have financial means to live longer when others can 
not? It seems to be a fiction but for Ray Kurzweill, the cofounder of the Singularity University [16], it is a reality eventhough, it will take time. Ray Kurzweill asserts that "the convergence of technologies will enable humanity in the horizon 2030 or 2050 , the advent of the moment where human spirit will be enhanced by artificial intelligence and where biological amortality will be realized." The author confirms that, some big firms like Google, Nokia, Paypal and the scientific institution like NASA are mobilising important financial means to label the enhancing biotechnology of fighting against man's mortality.

There is a general mobilisation all over the world to fulfill the desire of amortality. Precisely, the main efforts over the world are supplied by the USA, Japan, European Union: 3 billions of american dollar are invested, and more than one billion in Europe [17]. This simply describe the hegemonic ideology that is behind new biotechnologies and enhancing medecine in general. There is a new narcissic desire for great States of the world to colonize others, not from political perspective, but by genetic manipulation. In such a situation, bioethics has a central role to play. It must stop to be descriptive and critical and struggle to rethink human nature in the fluctuating process of biotechnologies.

\section{Rethinking Human Nature in the Biotechnologies: A Need for Transethics}

It is time to think about the outcome of biotechnologies as far as human nature is concerned. The purspose of all scientific activities has always been the well-being of man but the new biotechnologies seem to staint that purpose. By giving more consideration to experimentation and curiosity, biotechnology has become a danger to the future of huamn nature. Therefore, to prevent the opening of the Pandora's Box, bioethicists are bound to rethink the human nature. This will consist of not refounding human being, but to take some preventive measures in order to give garantee to the human being about a future desaster. This rethinking first of all consists of reminding ourselves about the limits of human power over nature and the possible upgrading of the ethics of today for an ethics capable of resilience towards biotechnologies.

\subsection{Remind the Limit of Man's Power over the Nature}

The assassination of God by Nietzsche in his philosophy of deconstruction gave an excess power to the human being. From this, man has been having the impression that his power has no limit over the universe, and that, he can manipulate, transform and dominate nature to his aim. That is why one can aknowledge the wish of Descartes who thougth in the Seventeenth century that science will make "man be the master and holder of nature". From the mastery of nature, man went beyond and pretends to master his own life through genetic engeneering.

The mastery of human life by human being himself is well describle by the British biologist Jennifer Doudna in his famous publication entitled $A$ crack in creation, the new power to control evolution in 2017. In this book, the coauthor shows that, genetic engeneering allows us to rewrite the genetic code that shapes and controls all living beings with astronishing accuracy and ease. With biotechnologies of enhancement, medical practices are no more searching for human well-being nor for is better-being but for human bestbeing. In penetrating in the very deep secret of life, physicians allegedly think of creating life, mastering the human genome and fighting against man's mortality. This is what the transhumanist Laurent Alexandre qualifies as the advent of "Artificial Life [18]." This misuse of man's power is susceptible to induce calamities on nature as well as on human life. It is thereby necessary and even urgent to remind the human being about the limit of his power and the consequences that his overpower can generate in his own life and which might be irreversible.

"When we know about all, we foresee nothing and when we know about nothing, we foresee all things ", states Claude Allegre, a french politician and scientist. This is a call for wisdom of upholders of biotechnology in the actual societies. It simply means that knowlege is good, but too much quest for knowledge and its misuse can plug humanity in a perilous situation. Human beings have the right to live and to live well but not to violate the natural law by altering the secret of the human genome. He must recognize his limit over the world and the limit of his knowledge. Some events have proved that the consequences of man's overpower in the universe can be desastrous. We have for instance the pandemy of Covid-19 which has shaked the world and about what, scientists are currently doubting on how to overcome it. It is then evident that the worst is still to come if man doesn't allow nature to regulate itself. It is not everything that science can explain or generate. We are not pretending to plomb the progress of science but we intend to uncloak the arrogance and the excessive pretention of human beings to dominate and create life. It is an urgent task to call for concern and to raise the debate according to Luc Ferry. The prudent lector of new biotechnology thinks that "the intention is neither to ban everything nor to empower all the practices, but to start thinking about the limits, to think over the measures of regulation which might awake the international community [19]." The author takes the position of the Golden Means about biotechnology. $\mathrm{He}$ is neither pessimistic nor too optimistic concerning genetic engeneering. According to him, genetic engeneering has overcome some untenable diseases and genetic disabilities like infertility, physical injuries of unborn children and so on. But this is not the reason to worship all the practices going on in biotechnology because some are not for human well-being but for selfishness and pretentious curiosity.

Luc Ferry's view is in line with the position of Francis Fukuyama, an American philosopher, who is very critical about the biotechnological innovations. The conception that Fukuyama has about the notion of human nature is very conservative and traditional. For him, genetic manipulation is 
prejudicial to human nature and can alter it. This is why the author is very prudential in his analysis. In his famous book entitled The last man: Consequences of the biotechnology revolution, Fukuyama calls for precaution in order to prevent the alteration of human nature and calamity in the world. He claims that:

They are good reasons of precaution which allow us to respect the natural order of things and prevent us to think that human beings can easily enhance themselves by an arbitrary intervention. Build a boundary or put in a monoculture in a given sector disturbs hidden relations and hurts the equilibrium of system in an unseen manner. It is the same case as well as human nature is concerned. There are many aspects of human nature that we heavely think to have understandood or that we want to improve if we had possibility. However, doing better than the nature is not always easy: the evolution is perhaps a hasardous process, but it follows a tight logic of adaptation that makes the organism suitable to their environment [20].

Despite the precaution to take, Fukuyama recognizes that biotechnologies will still evolve with very high speed and the regularion will be difficult. That ambivalent nature of biotechnologies calls for a new paradigm of ethics. This one lies on the resilience or what we qualifie as the transethics.

\subsection{The New Ethical Paradigm for Biotechnology: The Transethics}

Within biotechnology, the traditional ethics has failed because of its stiffness. Classical humanism by conceiving the human being as having an absolute and sacred value, doesn't want to succomb under the pratice of genetic engeneering in which the freedoom of mankind has no boundary. In this wise, one can talk of the "Collapse of the traditional ethics" using Singer's words. This collaspe must not be understood in the sense of Peter Singer who gave room to an ethical anarchism or moral relativism. What we intend to set here is an ethics of flexibility where, by accepting the progress of biotechnology, humanity must be able to fix its behaviour and its understanding concerning the notion of human nature.

Hence, the bioethical debate must also change its paradigm. This means that, the purpose of bioethicists is no longer to externally criticize or categorically reject some practices of biotechnology. There is a need for an accomodation and resilience, given the fact that no ethical discourse, no religious condamnation or even any political regulation can be able to handle the evolution of biotechnology. The main ethical question today is not how to slow down biotechnology but rather how to live with and contain the risks. That is why the attempt of bioconcervative movement is devoted to a crucial failure. In fact, transethics in our understanding is an ethics of resilience in which a medical practice is appreciated relating to its capacity of realizing the human well-being but not relating to the human nature. This is justified by the fact that any medical practice is an alteration to human nature. Even within the traditional paradigm, the simple medical intervention to cure a patient is already an alteration. Otherwise, the debate opposing therapeutic and enhancing medicine is not fondamental but rather heuristic. This difficulty is also acknowledge by Fukuyama in the following claim:

The distinction between therapy and enhancement has been attacked on the grounds that there is no way to distinguish between the two in theory, and therefore no way of discriminating in practice. There is a long tradition, argued most forcefully in recent years by the French postmodernist thinker Michel Foucault, which maintains that what society considers to be pathology or disease is actually a socially constructed phenomenon in which deviation from some presumed norm is stigmatized [21].

Let's take for example a couple which gives birth to a first child with a mucoviscidose (hereditary affection caraterised by a very high propension of viscisity of digestive secretion). If a second child is desired by the couple, a prenatal diagnostic will be necessary. Accordingly, preventive medecine must not be considered has ethically wrong because it helps to prevent an inherited disease that would give suffering to the new child. It is therefore ethically wrong to reject the preventive medecine even for the first pregnancy. There is no need for fear because bioetechnology doesn't care about emotion. Our culture is called to evolve and our habit to be revised. In order to face these profound mutations, transethics comes as a gateway for accomodation in the biotechnological society. The Twenty-first century is the era of deep revolution, we are tending to the achievement of another type of social relationship and another type of man. The conception of human nature will unavoidably be rethought, scientific discourse gives reliable meaning to human life and enables man to come over the most drastic difficulties. It is obvious that this revolution will set down new worries, but it is only within scientific framework that a solution must be found not by sterile and pessimistic debates. Once more the concept of transethics takes his whole significance.

\section{Conclusion}

Human nature in biotechnology goes through a real challenge. In traditional ethics as we stated, the human being was sacred and medical practice was based on the principle of sanctity of life. That is why the purpose of medicine was only therapeutic. The deeper revolution performed in medical domain pushed aside the old conception of human nature and has set down another version of medecine. Thereby, we moved from therapeutic medecine to enhancing medecine. Because human nature is not determinated, the physician can make experimentation and genetic manipulation over it. Enhancing medecine is the consequence of the attempt to change and alter human nature. Ethics has faced, henceforth difficulties in the field of biotechnology due to its stiffness. That is what we mean by the ethical principles under the challenge of enhancing medecine. 
Our concern is the destiny of human nature in the framework of biotechnology, mainly within enhancing medecine. It is already known that biotechnology, as it actually performs, is a real threat to human nature. However, the issue lies on the fact that we had been indoctrinated with the traditional conception of human nature. Time has come for humanity to stop resisting scientific progress but to rewrite the principles of our conduct. Bioethics must amend its focus. The critical and pessimistic versions of ethical debates have became obsolete because, despite those absolute principles, genetic manipulation carries on in the high discretion. Reason why we propose transethics as a reliable way of handling biotechnology today. It consits of an accomadation; that is, accepting biotechnological practices and appreciate them not relating to human nature but according to its capacity in fullfiling human well-being.

\section{References}

[1] Savulescu, J. (2009). «Genetic Enhancement». In Blackwell Companion to Bioethics, Second Edition, edicted by Helga Kuhse and Peter Singer, A John \& Sons, Ltd., Publication, p. 22.

[2] Beauchamp, T. and Childress, J. (2001). Principles of Biomedical Ethics. Fith Edition, New York, Oxford University Press, p. 114.

[3] Littré, E. Oeuvres Complètes d'Hippocrate., Paris, Librairie de l'Académie Royale de Médecine, 1841, Epidémie, Livre 1, 5 .

[4] Singer, P. (1996). Rethinking Life and Death: The Collapse of our Traditional Ethics. St. Martin's Griffin, New York, p. 57.

[5] Ameriks, K. and Clarke, D. (1998). «Immanuel Kant, Groundwork of the Metaphysics of Morals». In Cambridge Texts in the History of Philosophy, Cambridge University Press, p. xxii.

[6] Bouton, C. E. et al (2016). «Restoring Cortical Control of Functional Movement in a Human with Quadriplegia». Nature, 533, p. $247-250$.

[7] Savulescu, J. (2009). «Genetic Enhancement». In Blackwell Companion to Bioethics, Second edition, edicted by Helga Kuhse and Peter Singer, A John \& Sons, Ltd., Publication, pp. 218-219.

[8] Kuhse, H. and Singer, P. (2009). Blackwell Companion to Bioethics. Second edition, edicted by, A John \& Sons, Ltd., Publication, pp. 218-219.
[9] President's Council on Bioethics (2003). Beyond Therapy: A Report by the President's Council on Bioethics. Washington, DC: President's Council on Bioethics.

[10] Sandel, M. (2007). The Case Against Perfection: Ethics in the Age of Genetic Engeneering. Cambridge, MA: Havard University Press, p. 46.

[11] Damour, F. (2015). La Tentation Transhumaniste. Paris, Editions Salvator, p. 60.

[12] Baque, P. (2017). Homme Augmenté, Humanité Diminuée: D'Alzheimer au Transhumanisme, la Science au Service d'une Idéologie Hégémonique et Mercantile. Marseille cedex 20, Agone, p. 288.

[13] Kuhse, H. and Singer, P. (2009). Blackwell Companion to Bioethics. Second edition, edicted by, A John \& Sons, Ltd., Publication, pp. 126-127.

[14] Harris, J. (2007). Enhancing Evolution: the Ethical Case for Making Better People. Princeton \& Oxford, Princeton University Press, p. 124.

[15] Damour, F. (2015). La Tentation Transhumaniste. Paris, Editions Salvator, p. 39.

[16] Singularity University has been founded in 2009 by the americans Ray Kurzweil and Peter Diamandis, both futurist engeneers and physicists. The motto of the institution is make the impossible to be possible. The University is situated in the park of NASA near to Palo Alto enterprise alongside the Silicon Valley. Singularity in itself designates a particular human being endowed with the very high capacity of facing difficulties. For the founders, the Artificial Intelligence will realise later in 2035 the Artificial human being and technologies will evolve with the very high speed. I will be the end of man's mortality.

[17] Damour, F. (2015). La tentation transhumaniste. Paris, Editions Salvator, p. 57-58.

[18] Alexandre, L. (2014). La Mort de la Mort, Comment la Technomédecine va Bouleverser l'Humanité. Editions JeanClaude Lattès, p. 87.

[19] Ferry, L. (2016). La Révolution Transhumaniste, Comment la Technomédecine et l'Uberistaion du Monde vont Bouleverser nos Vies. Paris, Editions Plon, p. 26.

[20] Ferry, L. (2016). La Révolution Transhumaniste, Comment la Technomédecine et l'Uberistaion du Monde vont Bouleverser nos Vies. Paris, Editions Plon, p. 98-99.

[21] Fukuyama, F. (2002). Our Posthuman Future: Consequences of the Biotechnology Revolution. Farrar, Straus and Giroux, New York, p. 209. 